\section{Health Related Quality of Life Assessment questionnaire for children aged 5 to 11 years with HIV/AIDS: cross-cultural adaptation for the Portuguese language}

\author{
Questionário de Avaliação da Qualidade de Vida \\ para crianças de 5 a 11 anos com HIV/AIDS: \\ adaptação transcultural para a língua portuguesa
}

Luciana Scarlazzari Costa ${ }^{1}$

Maria do Rosário Dias de Oliveira Latorre 1 Norman Hearst 2

Heloisa Helena de Souza Marques ${ }^{3}$

\footnotetext{
${ }_{1}^{1}$ Faculdade de Saúde Pública, Universidade de São Paulo, São Paulo, Brasil. 2 Department of Family and Community Medicine, University of California, San Francisco, USA. ${ }^{3}$ Hospital das Clínicas, Universidade de São Paulo, São Paulo, Brasil.

Correspondence

L. S. Costa

Faculdade de Saúde Pública Universidade de São Paulo. Pça. General Tibúrcio 83 apto. 1417, Rio de Janeiro, $R J$ 22290-900 Brasil. scarla@usp.br
}

\section{Abstract}

The objective of this study is to describe preliminary results from the cross-cultural adaptation of the Quality of Life Assessment Questionnaire, used to measure health related quality of life (HRQL) in Brazilian children aged between 5 and 11 with HIVIAIDS. The cross-cultural model evaluated the Concept, Item, Semantic and Measurement Equivalences (internal consistency and intra-observer reliability). Evaluation of the conceptual, item, semantic equivalences showed that the Portuguese version is pertinent for the Brazilian context. Four of seven domains showed internal consistency above 0.70 ( $\alpha: 0.76-0.90)$ and five of seven revealed intra-observer reliability (ricc: 0.41-0.70). This first Portuguese version of the HRQL questionnaire can be understood as a valuable tool for assessing children's $H R Q L$, but further studies with large samples and more robust analyses are recommended before use in the Brazilian context.

Quality of Life; Acquired Immunodeficiency Syndrome; Child; Questionnaires

\section{Introduction}

In recent years, the development of a multidimensional measurement has been an important research concern, and a valid and reliable health related quality of life (HRQL) questionnaire is needed for children and adolescents with HIV/ AIDS 1,2.

A pediatric $\mathrm{HRQL}$ age specific questionnaire for HIV/AIDS patients has been proposed and validated by Gortmaker et al. 3. The questionnaire is based on a multidimensional conceptualization of health perceptions, physical resilience, physical functioning, psychological, social/role functioning, health care utilization and HIV-symptoms. This questionnaire was used in studies with HIV/AIDS infected children and has presented evidence of validity in this population $4,5,6$

The objective of this study is to describe preliminary results from the cross-cultural adaptation of the Quality of Life Assessment Questionnaire, used to measure HRQL in Brazilian children with HIV/AIDS aged from 5 to 11 years old.

\section{Methods}

\section{Study population}

The study was conducted between March 27 and August 20, 2005, at the Day Hospital, STD/ 
Aids Referral and Training Center, São Paulo (Hospital Dia, Centro de Referência e Treinamento em DST/Aids de São Paulo), with 35 children aged from 5 to 11 .

\section{Ethical considerations}

The Ethics Research Committee of the School of Public Health at the São Paulo University (Faculdade de Saúde Pública, Universidade de São Paulo; process no. 028/04) approved the study. All participants read and signed the informed consent.

\section{Recruitment}

The research was conducted by two trained student investigators, one with a $\mathrm{PhD}$, the other a master's degree. Socio-demographic questions for children and caregivers were based on caregiver reports. The HRQL was based on caregiver reports and all questions were completed by investigators. A medical history was collected from the patient's medical records at study entry.

\section{Health related quality of life questionnaire}

The questionnaire does not yield an overall summary score. Each domain is scored separately. In calculations of scale scores, raw item scores were reversed when necessary, summed, and then transformed to a scale ranging from 0 to 100 , with higher scores indicating better HRQL. The authors have presented the instructions and formulas for each domain score calculation, which can be found in Costa 7 .

\section{- Cross-cultural adaptation}

The adaptation process was based on the model used by Herdman et al. ${ }^{8}$. The following phases of the procedure were followed.

\section{Concept and items equivalence evaluation}

Discussions among three researchers (a Brazilian infectious disease specialist, fluent in English, a Brazilian epidemiologist and university professor, and a post-graduate student in Public Health) about the questionnaire items were made, in order to verify the item's pertinence, related to the original instrument and the instrument's relevance to the Brazilian context.

\section{Semantic equivalence evaluation}

First, the questionnaire was translated from English to Portuguese by the three researchers mentioned above. They discussed the discrepancies among the versions and reached a consensus about the Portuguese version.

Second, the Portuguese version was translated to English by an American physician, professor of Family and Community Medicine (University of California at San Francisco) who has English as a mother language (back translation). At this point, the equivalence between original and back translation was assessed, seeking to be a literal correspondence between the original and back translation, taking into account the cultural context of the target population.

Finally, the discrepancies were discussed and the Portuguese version of the HRQL questionnaire was, then, finished.

\section{- Measurement equivalence}

The Portuguese version was evaluated for internal consistency and intra-observer reliability.

\section{Statistical analysis}

Scale internal consistency was estimated by Cronbach's alpha coefficient.

The analysis of the intra-observer reliability (test-retest) was related to the reapplication of the HRQL questionnaire (30 to 45 days after the first interview). The reliability was assessed using Wilcoxon test and intra-class correlation coefficient (ICC).

\section{Results}

The study population (caregivers) was mostly made up of women ( $80 \%$ mothers) with elementary schooling, an average age of 38.6 years and average income of US $\$ 285.70$ per month. The children were mostly white girls who originally accessed the CRT/SP from 1996 to 2000.

\section{Concept and item equivalence evaluation}

The items of the original instrument were considered to represent adequately the HRQL dimensions in the Brazilian cultural context, but required a few changes.

In part B of the social/role functioning domain, there is one question about school levels, "What grade is your child in now" ("Qual o atual grau de escolaridade de seu filho?"), for which responses vary from "nursery/preschool" ("berçário/preescola” ) until "7th Grade” (“7a série”). Taking into account the school levels in Brazil, one grade, "8th Grade" ("8 a série") was added.

Another question in Part B of the social/role domain, is about children's home schooling, "Is 
your child receiving home schooling" ("Seu filho recebe aulas da escola em casa?"). This question was excluded, because this method does not take place in Brazil.

\section{Semantic equivalence evaluation}

In the back translation stage, there was generally consistent item equivalence between the back translation and the original instrument. Discrepancies were found between referential and general meaning.

The expression "jail sentence" means in the USA "prison", while in Brazil it can be meant as "detenção" or as "prisão". The solution adopted was the use of both "prisão/detenção".

The word "stepbrother/stepsister", literally translated to "irmão/irmã adotivo", has a wider English meaning: offspring, adopted or from other marriages. There is not a unique word in Portuguese that can describe offspring of other marriages, without biological relations. A longer term was therefore adopted: "irmão/irmã" or " filhos de outros casamentos dos pais” (sem vínculo biológico). These issues are part of a previous section of the questionnaire named clinical section and are not present in any HRQL domain.

The expression " $m y$ child is easily confused, seems to be in a fog", in psychological well-being dimension (question 8), has no literal translation to Portuguese. A linguistic adjustment was done: "Minha criança se confunde facilmente, parece estar um pouco fora do ar ou no mundo da lua".

Another question was adjusted in psychological dimension, question 9, "My child bullies or is cruel or mean to others". The word "bully" does not mean "valente" connected to the idea of "coragem", as it was translated, but it is connected to the idea of "agressividade", and that is why the word "intimidador" was chosen instead of the word "valente". So the Portuguese adjust- ment was done: "Minha criança é intimidadora ou é cruel com os outros".

\section{Measurement equivalence evaluation}

\section{- Internal consistency}

Table 1 shows $\alpha$ coefficients ranging from 0.11 to 0.90 . Although most alpha estimates were above 0.70 , estimates were lower than 0.70 for physical resilience, social/role functioning and health care service.

\section{- Reliability}

Almost all HRQL domains showed no difference in the means between test and retest. Differences were observed for physical functioning and symptoms domains (Table 2).

The intra-class correlation coefficients were significant for test and retest for almost all HRQL domain scores and the significant correlations were between 0.40 and 0.70 . No significant correlations were found for the role/social functioning and health care utilization domains (Table 2).

\section{Discussion}

This study describes the cross-adaptation of the quality of life questionnaire for children with HIV/AIDS from 5 to 11 years old.

The findings of the conceptual and items equivalence evaluation showed that the questionnaire items are relevant to the cultural context in Brazil. The changes in the questionnaire structure were minimal; two questions required more attention in the social/role functioning domain. One question about school level was modified according to the school levels in Brazil and another was excluded because children receiving

Descriptive statistics and internal consistency of health related quality of life (HRQL) questionnaire, for children with 5 to 11 years old. Centro de Referência e Treinamento em DST/Aids de São Paulo, São Paulo, Brazil, March 2005.

\begin{tabular}{|c|c|c|c|c|c|c|c|}
\hline \multirow[t]{2}{*}{ Parameter } & \multicolumn{7}{|c|}{ Domain -5 to 11 years $(n=35)$} \\
\hline & $\begin{array}{c}\text { Health } \\
\text { perceptions }\end{array}$ & $\begin{array}{l}\text { Physical } \\
\text { resilience }\end{array}$ & $\begin{array}{l}\text { Psychological } \\
\text { functioning }\end{array}$ & $\begin{array}{c}\text { Physical } \\
\text { functioning }\end{array}$ & $\begin{array}{l}\text { Social/Role } \\
\text { functioning }\end{array}$ & $\begin{array}{c}\text { Health care } \\
\text { utilization }\end{array}$ & $\begin{array}{l}\text { HIV-related } \\
\text { symptoms }\end{array}$ \\
\hline Mean (SD) & $78(17)$ & $81(18)$ & $66(11)$ & $86(20)$ & $86(8)$ & $93(6)$ & $87(11)$ \\
\hline Median & 80 & 86 & 68 & 92 & 93 & 96 & 92 \\
\hline Min-max & $42-100$ & $28-100$ & $36-89$ & $0-100$ & $67-93$ & $77-100$ & $59-100$ \\
\hline$\alpha$ Cronbach & 0.76 & 0.13 & 0.78 & 0.90 & 0.11 & 0.44 & 0.85 \\
\hline
\end{tabular}

SD: standard deviation. 
Summary of reliability evidences for health related quality of life (HRQL) questionnaire for children with 5 to 11 years old. Centro de Referência e Treinamento em DST/Aids de São Paulo, São Paulo, Brazil, March 2005.

\begin{tabular}{|c|c|c|c|c|}
\hline \multirow[t]{2}{*}{ Analysis } & \multirow[t]{2}{*}{ Variable } & \multirow[t]{2}{*}{ Comparison * } & Parameter & \multirow{2}{*}{$\begin{array}{c}\text { p-value } \\
\text { PWilcoxon test }\end{array}$} \\
\hline & & & Mean (SD) & \\
\hline \multirow[t]{22}{*}{ Reliability } & Health perceptions & Test vs. & $77.80(16.10)$ & 0.299 \\
\hline & & Retest & $80.80(14.70)$ & \\
\hline & Physical resilience & Test vs. & $83.70(15.20)$ & 0.853 \\
\hline & & Retest & $83.20(12.80)$ & \\
\hline & Physical functioning & Test vs. & $88.90(14.30)$ & 0.008 \\
\hline & & Retest & $96.10(8.40)$ & \\
\hline & Psychological functioning & Test vs. & $67.30(10.60)$ & 0.093 \\
\hline & & Retest & $70.30(12.40)$ & \\
\hline & Social/Role functioning & Test vs. & $86.40(8.00)$ & 0.245 \\
\hline & & Retest & $88.30(6.90)$ & \\
\hline & Health care utilization & Test vs. & $93.00(6.50)$ & 0.427 \\
\hline & & Retest & $91.80(6.00)$ & \\
\hline & HIV-related symptoms & Test vs. & $86.40(11.90)$ & 0.032 \\
\hline & & Retest & $90.80(8.00)$ & \\
\hline & & & $r_{\text {icc }}$ & Pintra-classe correlation \\
\hline & Health perceptions & Test vs. retest & 0.54 & 0.023 \\
\hline & Physical resilience & & 0.48 & 0.010 \\
\hline & Physical functioning & & 0.41 & 0.029 \\
\hline & Psychological functioning & & 0.70 & $<0.001$ \\
\hline & Social/role functioning & & 0.36 & 0.058 \\
\hline & Health care utilization & & 0.15 & 0.441 \\
\hline & HIV-related symptoms & & 0.53 & 0.004 \\
\hline
\end{tabular}

SD: standard deviation.

Note: $p<0.05$ statistically significant.

* Test-retest $(n=28)$.

home schooling is not part of the Brazilian context. In the semantic equivalence evaluation, just two expressions were modified in psychological domain - "my child is easily confused, seems to be in a fog" that was adapted to "Minha criança se confunde facilmente, parece estar um pouco fora do ar ou no mundo da lua", and "My child bullies or is cruel or mean to others" that was adapted by "Minha criança é intimidadora ou é cruel com os outros".

The adaptation did not show significant problems and corrections were properly done in the final Portuguese version.

The measurement equivalence results - internal consistency and reliability - must be interpreted considering the fact that the sample was based on the total number of patients available for the age group from 5 to 11 years old. Because of the limited sample size, the results from this analysis are preliminary and further studies are recommended to obtain better results in this evaluation.

It would be necessary to perform new and more robust analyses (factor and construct) with a large sample size before use in the Brazilian context. Otherwise, this first Portuguese version of the HRQL questionnaire can be understood as a valuable tool for assessing children's HRQL. 


\section{Resumo}

O objetivo deste estudo é descrever os resultados preliminares da adaptação, para o uso no Brasil, do questionário Quality of Life Assessment, usado para mensurar qualidade de vida relacionada à saúde (HRQL) em crianças com HIVIAIDS. O modelo de adaptação cultural considerou as avaliações de equivalência Conceitual, Itens, Semântica e de Mensuração (consistência interna e reprodutibilidade). As avaliações da equivalência conceitual, itens e semântica, mostraram que a versão para o Português é pertinente para o contexto brasileiro. Quatro de sete domínios apresentaram consistência interna acima de 0,70 ( $\alpha$ : 0.76-0.90) e cinco de sete apresentaram reprodutibilidade (ricc: 0.41 0.70). Esta primeira versão em Português do questionário de HRQL pode ser entendida como uma valiosa ferramenta para mensurar HRQL em crianças, porém outros estudos com amostras maiores e análises mais robustas, são recomendados antes do uso no contexto brasileiro.

Qualidade de Vida; Síndrome de Imunodeficiência Adquirida; Criança; Questionários

\section{Contributors}

L. S. Costa, M. R. D. O. Latorre and H. H. S. Marques contributed to the design of study, analysis and interpretation of data, writing, and critical review. N. Hearst contributed to translation, review and discussion of the paper.

\section{Acknowlegments}

To Fundação de Amparo à Pesquisa do Estado de São Paulo.

\section{References}

1. Eiser C, Morse R. Quality-of-life measures in chronic diseases of childhood. Health Technol Assess 2001; 5:1-95.

2. Garvie PA, Lawford J, Banet MS, West RL. Quality of life measurement in paediatric and adolescent populations with HIV: a review of the literature. Child Care Health Dev 2009; 35:440-53.

3. Gortmaker SL, Lenderking WR, Clark C, Lee S, Fowler MG, Oleske JM, et al. Development and use of a pediatric quality of life questionnaire in AIDS clinical trials: reliability and validity of the general health assessment for children. In: Drotar D, editor. Measuring health-related quality of life in children and adolescents: implications for research and practice. Mahwah: Lawrence Erlbaum Associates; 1998. p. 219-35.

4. Gaughan DM, Hughes MD, Seage III GR, Selwyn PA, Carey VJ, Gortmaker SL, et al. The prevalence of pain in pediatric human immunodeficiency virus/ acquired immunodeficiency syndrome as reported by participants in the pediatric late outcomes study (PACTG 219). Pediatrics 2002; 109:1144-52.

5. Storm DS, Boland MG, Gortmaker SL, He Y, Skurnick J, Howland L, et al. Protease inhibitor combination therapy, severity of illness, and quality of life among children with perinatally acquired HIV-1 infection. Pediatrics 2005; 15:173-82.

6. Lee GM, Gortmaker SL, McIntosh K, Hughes MD, Oleske J; Pediatric AIDS Clinical Trials Group Protocol 219C Team. Quality of life for children and adolescents: impact of HIV infection and antiretroviral treatment. Pediatrics 2006; 117:273-83.

7. Costa LS. Quality of life in children and adolescents with HIV/AIDS. Instrument's validity and reliability [Doctoral Dissertation]. São Paulo: Faculdade de Saúde Pública, Universidade de São Paulo; 2007.

8. Herdman M, Fox-Rushby J, Badia X. A model of equivalence in the cultural adaptation of HRQoL instruments: the universalist approach. Qual Life Res 1998; 7:323-35.

Submitted on $14 /$ Jun/2010

Final version resubmitted on 25/Feb/2011

Approved on 07/Apr/2011 